\title{
Effect of Bedding Materials on Growth and FCR in Barbari Kids during Winter Season
}

\author{
Mohit Antil ${ }^{1 *}$, Bhuvaneshwar Rai ${ }^{2}$, Ramachandran Natesan ${ }^{2}$, \\ Chetna Gangwar ${ }^{2}$ and Seema Yadav ${ }^{1}$
}
${ }^{1}$ Livestock Production Management division, Indian Veterinary Research Institute, Izatnagar, Bareilly-243122, India
${ }^{2}$ Animal Physiology and Reproduction division, Central Institute for Research on Goats, Makhdoom, Mathura-281122, India

*Corresponding author

\section{Keywords \\ Barbari kids, Bedding material, Growth, FCR, Winter season \\ Article Info \\ Accepted: \\ 15 January 2019 \\ Available Online: \\ 10 February 2019}

\section{A B S T R A C T}

The present study was conducted in AP\&R division of CIRG, Makhdoom, to investigate the effect of different bedding materials during winters on growth of Barbari kids. Thirty Barbari kids of about three months age and average body weight $10.26 \pm 0.42 \mathrm{~kg}$ were divided into three equal groups (Gr I, Gr II and Gr III) of ten animals each. The animals in Gr II served as control and were provided with soil as a bedding material, while animals in Gr I and Gr III were provided with plastic slats and rubber mats as bedding materials, respectively. Duration of experiment was 90 days (3 month to 6 month age of kids). Body weight of kids was recorded first before shifting the goats to the respective treatments and thereafter all the experimental animals were weighed at fortnightly interval i.e. on $0,15^{\text {th }}$, $30^{\text {th }}, 45^{\text {th }}, 60^{\text {th }}, 75^{\text {th }}$ and $90^{\text {th }}$ day. The recording was done before offering feed and water to the kids. The performance of kids in terms of body weights, average daily gain and FCR was similar $(\mathrm{P}>0.05)$ among the kids of different groups. Present study concluded that provision of different bedding materials viz. plastic slats, rubber and soil had similar effect on performance of the Barbari kids in terms of growth and nutrient utilization.

\section{Introduction}

Goat, which is also known as 'Poor man's cow', is an important source of income for the marginalized section of rural population that owns majority of the small ruminants (Ali et al., 2007). A persistent rise in demand for animal products due to changes in consumer tastes and expanding markets; particularly in developing countries showing expansion in wealth has created a challenge for animal scientists to meet this demand by optimization of housing for better production (Hopkins $e t$ al., 2007).

Barbari goats are small, short-haired and distributed across Uttar Pradesh and Rajasthan States of India; the most typical colour is white with small light brown patches (Acharya, 1982). The highly prolific breed is 
quite important for milk and meat and highly suited for rearing under stall-fed conditions.

Housing system had a significant effect on body weight (Kovnerev and Smironov, 1988). Assuring appropriate housing provides one means of modifying stressful environmental conditions and ensuring proper growth (Pusillo et al., 1990). The main problem of kid rearing is the post-weaning poor growth which is significantly affected by housing management (Dadi et al., 2008; Gbangboche et al., 2006). Different management systems can be assessed by using growth rates which is an effective tool and indicator of good health. Better growth rates indicate towards enhanced general adaptability and feed conversion efficiency of animals. Bedding material is a vital component of housing for kids during winters. The essential functions of the bedding material are its ability to abate the extremes of climatic stress and providing conducive microclimatic conditions (Rahman et al., 2013). Therefore, the present study was conducted to assess the effect of bedding materials on growth performance of barbari kids in winter season.

Acharya RM. Sheep and goat Breeds of India. FAO Animal

Production and Health Paper 30. pp. 62-64, FAO, Rome,

1982.

\section{Materials and Methods}

The present study was conducted at Experimental shed complex on ICAR-Central Institute for Research on Goat (C.I.R.G) Makhdoom, Mathura, Uttar Pradesh, India. The climate is hot and semi-arid. Weather turns colder with winter stretching from November to February and summer ranges from May to August month annually. The animal experiment was initiated in December 2017 and ended in March 2018. A total of 30 post weaned Barbari kids (21 males and 9 females) aged 3 months were selected from institute flock. The kids were randomly allocated to the two treatment groups (Plastic slats and rubber mat) and one control group (Soil floor) on the basis of similar body weight.

Each group comprised of ten kids (7 males and 3 females). While selecting the animals, due care was taken to minimize the error by narrowing down the range of age and live weights of these experimental animals as far as possible. The study was conducted for a period of 90 days duration with an adaptation period of 1 week prior to recording of variables. The animals were raised under an intensive housing system. A single pen (400 feet $^{2}$ ) was partitioned equally into 4 parts using welded wire mesh. The control and treatment groups were housed in separate partition of the pen having different bedding materials. Out of the three groups, second group served as control.

Body weight of kids was recorded first before shifting the goats to the respective treatments and thereafter all the experimental animals were weighed at fortnightly interval i.e. on 0 , $15^{\text {th }}, 30^{\text {th }}, 45^{\text {th }}, 60^{\text {th }}, 75^{\text {th }}$ and $90^{\text {th }}$ day. The recording was done before offering feed and water to the kids. The total weight gain $(\mathrm{kg})$ was calculated by difference between final body weight and initial body weight i.e. birth weight of calves. Average daily gain $(\mathrm{kg})$ was calculated based on total body weight gain and number of days for study.

\section{Statistical analysis}

The experimental data generated were analyzed using one way or two way ANOVA (statistical package SPSS 20.0) and means were compared using Duncan's multiple range test. The $\mathrm{P}$ values less than 0.05 were taken to indicate statistical significance by 
adopting standard statistical procedures (Snedecor and Cochran, 1994).

\section{Results and Discussion}

\section{Dry matter intake}

Overall dry matter intake (DMI) of the kids in different groups is presented in Table 2. Mean DMI $(\mathrm{kg})$ in the all groups was comparable $(\mathrm{P}>0.05)$ being 569.72, 590.49 and $558.70 \mathrm{~g} / \mathrm{d}$, in Group-I, II and III respectively showing no significant effect of bedding materials on DMI in the kids (Table
1). The findings are in agreement with previous studies showing no significant effect on feed intake of animals provided with different beddings. Similar findings were reported by Bhatta et al., (2005) in sheep and Cozzi et al., (2013) in young bulls raised under different flooring types. In contrary, a positive effect of floor type on dry matter intake in ruminants was reported by Zervas $e t$ al., (1999), Bhakat and Nagpaul (2005), Karim et al., (2007), Singh et al., (2008), Kumari et al., (2013) and Rahman et al., (2013).

Table.1 Dimensions of partitions of pen made for different groups

\begin{tabular}{|c|c|c|}
\hline Group & Bedding material used & Dimensions of partition \\
\hline $\mathbf{1}$ & Plastic Slats & 10 feet $\times 10$ feet \\
\hline $\mathbf{2}$ & Soil & 10 feet $\times 10$ feet \\
\hline $\mathbf{3}$ & Rubber mats & 10 feet $\times 10$ feet \\
\hline
\end{tabular}

Table.2 Overall performance in different groups of kids during the trial

\begin{tabular}{|c|c|c|c|c|c|c|}
\hline Attribute & Group I & Group II & Group III & Mean & SEM & P Value \\
\hline $\begin{array}{c}\text { Avg. Dry matter } \\
\text { intake (g/d) }\end{array}$ & 569.72 & $\begin{array}{l}590.4 \\
\text { TBW Gain (kg) }\end{array}$ & 558.70 & 572.97 & 7.05 & 0.175 \\
\hline FCR & 8.11 & 5.94 & 5.77 & 5.91 & 0.32 & 0.955 \\
\hline FCE (\%) & 13.36 & 12.74 & 8.43 & 8.45 & 0.53 & 0.874 \\
\hline Initial body wt. & 10.29 & 10.24 & 10.24 & 13.06 & 0.71 & 0.942 \\
\hline Final body wt. & 16.30 & 16.19 & 16.02 & 16.17 & 0.42 & 0.999 \\
\hline ADG (g/d) & 76.13 & 75.25 & 73.10 & 74.83 & 4.06 & 0.984 \\
\hline
\end{tabular}

Table.3 Effect of different bedding materials on fortnightly body weight $(\mathrm{kg})$ changes of kids in different groups

\begin{tabular}{|l|l|l|l|l|l|l|}
\hline Weight gains & Group I & Group II & Group III & Mean & SEM & P Value \\
\hline $\mathbf{1}^{\text {st }}$ Fortnight & 10.29 & 10.24 & 10.24 & 10.26 & 0.42 & 0.999 \\
\hline $\mathbf{2}^{\text {nd }}$ Fortnight & 10.91 & 10.88 & 10.75 & 10.85 & 0.46 & 0.990 \\
\hline $\mathbf{3}^{\text {rd }}$ Fortnight & 12.40 & 12.41 & 12.06 & 12.29 & 0.48 & 0.948 \\
\hline $\mathbf{4}^{\text {th }}$ Fortnight & 13.02 & 12.86 & 12.34 & 12.74 & 0.50 & 0.859 \\
\hline $\mathbf{5}^{\text {th }}$ Fortnight & 14.35 & 14.19 & 13.70 & 14.08 & 0.54 & 0.884 \\
\hline $\mathbf{6}^{\text {th }}$ Fortnight & 15.38 & 14.93 & 14.91 & 15.07 & 0.58 & 0.939 \\
\hline $\mathbf{7}^{\text {th }}$ Fortnight & 16.30 & 16.19 & 16.02 & 16.17 & 0.62 & 0.984 \\
\hline Overall & 13.23 & 13.10 & 12.86 & 13.06 & 0.23 & 0.811 \\
\hline
\end{tabular}




\section{Body weight changes of kids in different} groups

The fortnightly body weight changes of kids in different groups were measured and are presented in table 3. The average initial weights $(\mathrm{kg})$ of kids in Group-I, II and III were $10.29,10.24$ and 10.24 , respectively. There was no significant difference $(\mathrm{P}>0.05)$ in initial body weight. There was a progressive increase in body weights of kids as they advanced in age (Table 3).

The average daily gains (g) of kids in Group I, II and III were 76.13, 75.25 and 73.10, respectively (Table 2). The final body weights of kids were $16.30,16.19$ and $16.02(\mathrm{~kg})$ in Group -I, II and III, respectively. There was no significant difference $(\mathrm{P}>0.05)$ in initial total body weight gain and average daily gain of kids between different groups but they were found to be marginally better in GroupI, as depicted in Table 3.Thiruvenkadan et al., (2009) also reported the effect of slatted floor on growth rates were comparable with mud floor. Similarly, effect of bedding material on production parameters like feed intake, live weight and carcass quality was nonsignificant (Lowe et al., 2001; Chikwanda and Muchenje, 2017). In contrary, Bhakat and Nagpaul (2005) and Bharambe and Shinde (2014) found that kids raised on slatted floor exhibited better growth rates.

\section{FCR and FCE}

FCR and FCE in different group of kids are presented in Table 2. The feed conversion ratio (FCR) of kids in Group-I, II and III was $8.11,8.81$ and 8.43 , respectively. The feed conversion efficiency (FCE) of kids in GroupI, II and III was found to be 13.36, 12.74 and 13.08, respectively. In this study no significant difference $(\mathrm{P}>0.05)$ in the FCR and FCE was reported among different groups which is consistent with the findings of
Rahman et al., (2013). Earley et al., (2017) and Keane et al., (2018) also reported similar findings in finishing beef steers housed on various floor types. FCR and FCE were found to be marginally better in Group-I as compared to Group-II and III. The values of FCE exhibited during the study were found to be congruent with values found by Khan and Singh (1995) in Barbari kids.

In conclusion, bedding material is one of the most vital components of housing of kids during winters. The bedding material can help in augmentation of animal welfare and health. Lack of appropriate bedding may lead to uncomfortable conditions during winters, which consequentially hampers the productivity of livestock making them prone to different diseases and parasitic infestation (internal and external). Provision of different bedding materials viz. plastic slats, rubber and soil had similar effect on growth performance of the Barbari kids. Further studies are required to gain more insights regarding bedding materials.

\section{References}

Acharya, R. M. Sheep and goat Breeds of India. FAO Animal Production and Health Paper 30. pp. 62-64, FAO, Rome, 1982.

Ali, J. 2007. Livestock sector development and implications for rural poverty alleviation in India. Liv. Res. For Rural Dev.2:1-15.

Bhakat, C. and Nagpaul, P.K. 2005. Effect of housing systems on the growth performance of crossbred goats. Indian J. Anim. Sci.75: 69-73.

Bharambe, V.Y. and Shinde, S.S. 2014. Effect of different housing systems on performance of Osmanabadi kids in Konkan region of India. Indian J. of Small Rum. 20(2):132-133.

Bhatta, R., Swain, N., Verma, D.L. and Singh, 
N.P. 2005. Effect of housing on physiological responses and energy expenditure of sheep in a semi-arid region of India. Asian Aust. J. Anim. Sci. 18: 1188-1193.

Chikwanda, A.T. and Muchenje, V. 2017. Grazing system and floor type effects on blood biochemistry, growth and carcass characteristics of Nguni goats. Asian-Australasian Journal of Animal Sci. 30(9):1253-1260.

Cozzi, G., Tessitore, E., Contiero, B., Ricci, R., Gottardo, F. and Brscic, M. 2013. Alternative solutions to the concrete fully-slatted floor for the housing of finishing beef cattle: Effects on growth performance, health of the locomotor system and behaviour. Vet. J. 197: 211215.

Dadi, H., Duguma, G., Shelima, B., Fayera, T., Tadesse, M., Woldu, T. and Tucho, T. A. 2008. Non-genetic factors influencing post-weaning growth and reproductive performances of Arsi-Bale goats. Liv. Res. For Rural Dev. 20(7)

Earley, B., McNamara, J. D., Jerrams, S. J. and O'Riordan, E. G. 2017. Effect of concrete slats, three mat types and outwintering pads on performance and welfare of finishing beef steers. Acta Vet. Scand. 59: 34.

Gbangboche, A. B., Adamou-Ndiaye, M., Youssao, A. K. I., Farnir, F., Detilleux. J., Abiola, F. A. and Leroy, P. L. 2006. Non-genetic factors affecting the reproduction performance, lamb growth and productivity indices of Djallonke sheep. Small Rum. Res. 64(1):133-142.

Hopkins, D. L., Stanley, D. F., Toohey, E. S., Gardener, G. E., Pethick, D. W. and Van de Ven, R. 2007. Sire and growth path effects on sheep meat production 2. Meat and eating quality. Aust. J. Experi. Agri. 47:1219-1228.

Karim, S.A., Porwal, K., Kumar, S. and Singh, V.K. 2007. Carcass traits of
Kheri lambs maintained on different system of feeding management. Meat Sci. 76: 395-401.

Keane, M. P., McGee, M., O’Riordan, E. G., Kelly, A. K. and Earley, B.2018. Effect of floor type on performance, lying time and dirt scores of finishing beef steers. Liv Sci. 212: 57-60.

Khan, B.U. and Singh, S.K. 1995. Genetics of feed conversion efficiency in Barbari goats. Small Ruminant Res. 15: 283285.

Kovnerev, I.P. and Smironov, A.V. 1988. The effect of housing conditions on viability of lambs. Ovtsevodstvo2: 28-29.

Kumari, A., Baig, M.I., Kodape, A.H., Dagli, N.R., Patwardhan, S.H. and Ghorpade, P.P. 2013. Growth performance of Osmanabadi kids under different housing systems. Ind. J. Small Rum. 19: 215-216.

Lowe, D.E., Steen, R.W.J., Beattie, V.E. and Moss, B.W. 2001. The effects of floor type systems on the performance, cleanliness, carcass composition and meat quality of housed finishing beef cattle. Livestock Production Science 69: 33-42.

Pusillo, G.M., Hoffman, M.P. and Self, H.L. 1990. Effects of placing cattle on feed at two-month intervals and housing on feedlot performance and carcass grades. J. Ani. Sci. 69: 442-450.

Rahman, A., Nagpaul, P.K. and Singh, B., 2013. Effect of two different shelter systems on milk yield and composition feed intake, feed conversion efficiency and physiological responses in lactating crossbred goats during winter season. Egyptian J Sheep Goat Sci. 8(1): 81-87.

Snedecor, G.W. and Cochran, W.G. 2004. Statistical methods. 9th ed. The Iowa State University Press, Ames, Iowa, USA.

Singh, D.V., Singh, S.K., Patel, M. and Kumar A. 2008. A new dimension to 
comfortable housing of goats in Tarai region. Indian J. Ani. Prod. Mgmt. 24(3-4): 120-123.

Thiruvenkadan, A.K., Murugan, M., Karunanithi K., Muralidharan J., Chinnamani K. 2009. Genetic and nongenetic factors affecting body weight in
Tellicherry goats. South African J Anim Sci. 39(Suppl. 1): 107-111.

Zervas, G., Hadjigeorgiou, I., Zabeli, G., Koutsotolis, K. and Tziala, C. 1999. Comparison of a grazing with an indoor system of lamb fattening in Greece. Livest. Prod. Sci., 61: 245-251.

\section{How to cite this article:}

Mohit Antil, Bhuvaneshwar Rai, Ramachandran Natesan, Chetna Gangwar and Seema Yadav. 2019. Effect of Bedding Materials on Growth and FCR in Barbari Kids during Winter Season. Int.J.Curr.Microbiol.App.Sci. 8(02): 1930-1935. doi: https://doi.org/10.20546/ijcmas.2019.802.224 